\title{
TALKING TO TEACHERS ABOUT SOCIAL DIALECTS
}

\author{
Robbins Burling \\ University of Michigan
}

\begin{abstract}
Linguists have recently become aware of the agonizing problems faced by school children who speak non-standard English. When these children learn to read, they must cope not only with a certain amount of linguistic interference, but also with the severely deprecatory attitudes of their teachers toward their dialect. Linguists have a responsibility to help teachers learn more about the nature of dialectical variability and, in particular, about non-standard English. Helping teachers is often difficult, however, for they start with assumptions about language that differ so radically from the assumptions of linguists that it is sometimes difficult to achieve an intelligible dialogue. Linguists must find ways to make their knowledge meaningful to teachers. They must not bury teachers in technical complexities but offer their insights in ways that will strike the teacher as relevant to the practical concerns of their teaching. Some personal experiences are recounted that may help other linguists to avoid certain pitfalls as they try to enter into communication with teachers.
\end{abstract}

\section{Introduction}

In the last five years linguists have suddenly and belatedly become aware of the degree of dialect variation that separates the social classes of the United States. After decades of disgraceful ignorance a new generation of linguists has finally turned its attention to the characteristics of non-standard English and, in particular, to the varieties of English used by many lower class black Americans. We now have a new social or "vertical" dimension to dialectology that supplements and illuminates the older more exclusive attention to the geographical or "horizontal" dimension.

This work is important for dialectology, for historical linguistics, and for general linguistic theory, but it also has profound implications for the practical day-to-day education of the millions of American children who use a non-standard dialect of English. To the linguist it seems obvious that most of the reading and spelling workbooks used by our schools are quite out of harmony with the phonological characteristics of many non-standard dialects, but most teachers have no idea that their pupils have a different system of phonological contrasts or different sets of homonyms than their own. As a result teachers often present sound-letter correspondences in ways that are quite mysterious to their children. 
Some grammatical characteristics of non-standard English can present problems to children who are given reading materials based on grammatical forms not found in their native speech, but instead of approaching the matter as one of quasi-foreign language learning, most teachers continue to assume that some grammatical forms are simply wrong. Their deprecatory attitude toward the language of their pupils inevitably affects their general attitude toward the children. Teachers expect children who use "poor" language to fail, and their expectations are easily communicated to their pupils who readily fulfill their teacher's prophesies. The children of poverty, the children who come from neighborhoods where some form of non-standard English is the every-day colloquial language, are failing in terrifying numbers in every ghetto schoolroom in the country.

Any linguist who becomes aware of the abysmal lack of understanding of simple linguistic principles which daily confounds education in thousands of urban classrooms is in danger of developing a compulsion to charge forth to educate the educators. Surely teachers should be told about the nature of dialect differences! Surely they can learn to adopt a rational approach to children with a different dialect from their own! Surely they can help these children to build on their native speech patterns as they learn to read! If children must learn a new dialect, they ought to be helped to do so without being made ashamed of their own.

Sadly, however, linguists who have tried to make contact with teachers have often felt considerable discouragement and frustration. I have tried to organize a course that would focus upon the nature of non-standard English and upon the implications of the dialect for education. I have tried to use this course to reach teachers, but I have had trouble persuading them that I had anything important to say. I have had difficulty presenting my material in ways that would stimulate or excite them, and by standards of achievement that seem reasonable to a linguist, they have often performed rather poorly. I have found that teachers and linguists start with such different assumptions and such a different outlook on language that they often find difficulty in talking to each other. I would suggest that a linguist who is struggling to talk to teachers might avoid a few of the worst problems if he would be on guard from the outset against two particularly likely areas of misunderstanding.

First, all linguists should be warned about the narrow vocational orientation of most teachers and students in education. Those I have dealt with have tended to view general or theoretical approaches with suspicion, and to look instead for immediately 
applicable practical solutions. City teachers realize that they face a language problem. They know that some sort of language barrier interferes constantly with their classroom work. But, when I urge them to sit back and consider the situation, to think about the nature of language or the nature of dialect differences, they tend to respond with the attitude: "I don't want to be bothered with all those abstract theories. Just tell me what to do." One student put the matter concretely when she admitted that my discussion of grammatical differences between standard and non-standard English might be interesting but, she said, she was on the firing line and needed something much more concrete.

The second difficulty is simply the emotional nature of the issues. People have deep feelings about their language. Black students feel seriously threatened by public recognition of linguistic forms that they have long struggled to suppress. You can protest that everyone speaks a "dialect," and that you mean to take "black dialect" seriously. You can insist that you view it with respect and that you regard it as a worthy medium of communication. You can argue that by failing to consider its nature, we simply condemn countless school children to failure. Such protestations may seem to be accepted intellectually, but it is exceedingly difficult for some black students to accept them emotionally. The subject cuts too close to the soul. White students come to the subject with a different set of hangups, but they may be almost as severe. Many find any discussion of linguistic differences to be, at a minimum, embarrassing and, at most, to smack of prejudice. Somehow it is impolite to speak of these things. Courtesy seems to demand that we ignore them.

I have horrid and vivid memories of the day my class rebelled at arrangements I had made for visits to elementary classrooms in Detroit's inner city. A black student suggested that it was not proper to go and look at black children as if they were guinea pigsa terribly threatening suggestion to his white classmates. Another student, engaged at that time in his first practice teaching, said he would find a visit such as I had arranged to be an unwelcome intrusion upon his own class. A somewhat radically-oriented student felt that the very idea of white college students visiting predominantly black schools would be a symbol of racism and exploitation. After an emotional hour of hand wringing, several students decided not to visit classes. I suspect that some were simply afraid to venture into a predominantly black school and into a predominantly black part of town. They succeeded, however, in rationalizing their fear in a way that avoided facing up to their own prejudices. 
Mistakes

My first attempts to talk with teachers were certainly fumbling, but in the hope that others might profit from my own mistakes, I can offer a few observations on what now seem to me to have been misjudgments on how to organize a course for teachers.

1) Linguistic prerequisite. I first supposed that at least one course in general linguistics was a necessary background to any course that would deal seriously with the implications of social dialects for education. I knew this would limit my audience, but I did not realize just how narrow the limits would be. Our experience at The University of Michigan has been that relatively few students from the School of Education take courses in general linguistics, and those who do frequently perform poorly. Many teachers fail to see the relevance of the subject for their vocational goals and they have little interest in the kinds of topics that tend to be stressed in a general course in linguistics. Only a very small number emerge from such a course with enough enthusiasm for the subject to be willing to submit themselves to an additional course. After some false starts, therefore, I have concluded that it is best to dispense with a prerequisite. The necessary minimum of linguistic theory can be presented as the need arises.

2) Diversity of backgrounds. One of my reasons for first insisting upon a linguistic prerequisite was to allow me to organize a course that would be of some interest to linguists as well as to teachers. There was a modest demand among students in the Department of Linguistics for a course that would concentrate upon English social dialectology, and I wanted to respond to that need. I also wanted to experiment with putting teachers and linguists into the same classroom, for I had hoped they might in that way become aware of each other's concerns.

I have been gratified by the comments of a number of linguistics students who found it fascinating to be with the teachers. They were intrigued by the problems the teachers face and by the kinds of questions they raised. From the side of the teachers, however, the experiment was not a success. Not even a previous course in linguistics gave them the confidence to meet the linguists half-way. Instead of learning from the linguists they were intimidated by them, and they would tell me after class how mysterious they found the linguists' questions. The theoretical discussions that followed these questions did nothing but discourage and alienate the vocationally-oriented teachers.

Thus, I have come to the reluctant conclusion that the needs of the teachers can be better met if linguists are excluded or at least admitted only with the clear understanding that the class is not designed for them, and that they are 
under strict orders to refrain from tossing about intimidating terminology.

3) Degree of technicality. Having decided to admit students with no background in linguistics, I still faced the problem of how to present enough general linguistics to allow social dialects to be considered with some degree of sense. At one time I thought I had solved this problem by setting aside certain days when I would go over fundamental concepts for the benefit of those without previous background. Better prepared students were excused. Those who came received some basic phonetics and a couple of hours on general syntax. Trying to squeeze too much into these few days, I surely alienated some of my students. At the same time, since some students had been excused, I avoided material bearing directly on dialect problems, for I wanted to treat these matters when everyone was present. In this way I reduced even further any appearance of relevance to the practically-oriented teachers who remained. I have now concluded that it is better not to separate theoretical matters from the more applied discussion of dialectical differences.

Of course, if one is to talk sense about dialects, he must present some general linguistic notions. I do not see how any reasonable discussion of phonological differences can proceed without some understanding of the notion of contrast, nor do I see how negative concord can be discussed without some grasp of the assumptions that linguists make when they study syntax. Nevertheless, anyone willing to bend a bit will find a good many technicalities to be quite dispensable. I find, for instance, that phonetic terminology can be avoided almost entirely. When necessary, the placement of tongue and lips can be described and demonstrated for those particular sounds that have importance to the immediate discussion. Phonetic symbols can be intimidating, but teachers are well acquainted with the symbols used in popular dictionaries, and a linguist should be adaptable enough to accept these. I have learned to talk about "pronunciation, grammar, and vocabulary," rather than "phonology, syntax, and lexicon," and I can say "blend" so that the teachers do not have to struggle with "cluster." As I have gradually learned to eliminate technical terms from my speech and to resort to technical discussion only when it bears directly upon dialect differences, I have made my course less appropriate for students with a linguistic background, but students whose major interest is linguistics may be better served in other ways. By reducing technicalities and staying closer to questions of dialect, I have gone part-way toward meeting the demands of the teachers for practical applicability. They do not conclude so quickly that 
the subject is too esoteric to have importance for their classroom needs.

4) Promises of applicability. One cannot, however, go all the way in meeting the teacher's demands for immediate assistance with immediate problems. I am unwilling to suggest lesson plans, and I continue to feel that my contribution is to offer a better general understanding of the linguistic situation, not to give specific instructions about how to teach children. Having learned to my dismay of the narrow vocational orientation of so many teachers, I now feel it is extremely important not to promise too much. A linguist is tempted to claim importance for the things he has to say. He wants every teacher to know what he knows. But if he asserts his claims too insistently, teachers are likely to interpret them as promises for something approaching lesson plans. It is important, therefore, to state clearly and at the beginning that you will try to offer a general view of some aspects of language and of variation in language as it is used in and out of the classroom, but that you are not giving a course in teaching methods and will not suggest lesson plans.

An additional factor needs to be recognized at this point. The term linguistics is currently having something of a fad in education circles. A linguist finds it instructive to visit the publisher's booths at teacher's conventions. Book salesmen proudly announce that their series are based upon the "linguistic method." It is both amusing and depressing to pretend naivité and ask these salesmen what is meant by "the linguistic method" for they really have no idea. They talk about mere gimmicks that bear only the faintest resemblance to anything a linguist would recognize as coming from his own field. Intelligent teachers, bombarded by these phony claims for some magic "linguistic method," are likely to become properly suspicious of self-proclaimed experts bearing linguistic gifts. Linguists who promise help, and then deliver obscure technical terminology and abstract theory simply confirm the suspicions of the teachers. It is better to promise little and offer something, than to promise much and deliver less.

5) The relative priorities of facts and theories. My preference in teaching has always been to start with data and then to ask how we can best handle it. I like to build from the data to the theories we construct. Thus, when I first wanted to inform students about black English, I found it natural to start by playing tapes of black non-standard speech to the class and to proceed from what we heard to a discussion of the general principles that would help us to understand what was in the tape. By playing tapes at the 
beginning, I hoped I might catch the imagination of students.

I am afraid, however, that I did more to alienate them than to excite them. Americans have an all too readily available theory to explain the difference between standard and non-standard English-they take it quite for granted that some ways of speaking are correct and others are simply the result of ignorance or carelessness. Playing tapes too early simply confirms this presumption. I have driven students away from my course by playing tapes too early. They were acutely embarrassed, and some found the experience more than they could bear.

Thus, I have concluded that a different order of presentation is needed. I first describe the general nature of phonological variation starting with variation that involves no stigmatization, and then move on to stigmatized pronunciations. Only later do I play a tape that demonstrates the things we have talked about. The threat to the students is reduced, and they are able to accept the recordings as confirmation of their new linguistic knowledge rather than as confirmation of their older (if suppressed) sociological prejudices.

6) Evaluation. I first tried to base my evaluation on papers of various sorts rather than upon examinations. I encouraged my students to find speakers and study their speech, or at least to listen to tapes or to analyze written materials that show the influence of non-standard English. I felt, and I continue to feel, that a well motivated and intelligent student can, even at an elementary level, learn a great deal by listening to and analyzing features in a dialect quite different from his own.

Many teachers, however, find this task to be very foreign. They often propose doing a more applied paper (working up lesson plans for instance) and it takes a good deal of the term before they gain enough confidence to listen to or describe other dialects. When they finish, moreover, I have felt uneasy about interpreting their products. I am never quite sure just how much they have really learned. I have come to the conclusion, therefore, that an old fashioned examination is not such a bad idea after all. Teachers do not feel insulted by the idea, and it does (sad though the fact may be!) stimulate students to complete their assignments and to try to integrate the various things they read and hear. I also find short exercises handed in at various times during the term to be useful. They stimulate the students to summarize and integrate what they have been studying, and they help me to gain some idea of how much they understand, but I do not like to take such exercises seriously as a means of assigning grades. 
A course that seemed to work.

As I fumbled with these problems, I became more and more discouraged about my ability to make productive contact with teachers, but a recent attempt with a six weeks summer extension course in Flint, Michigan, has renewed my hope. Flint offered a number of advantages over the main Ann Arbor campus of The University of Michigan. For one thing, the course was shorter and more concentrated. Meeting for only twelve 2-1/2 hour sessions, it had clear and foreseeable limits. We could all see the end coming. I was less tempted to cram too much in, and if the students occasionally found the subject distressing, they knew, at least, that it would soon be over. The conventional term may be just a bit too long.

Fortunately, moreover, the class had about eight black students so none of them ever needed to feel alone, or to feel himself to be a unique object of inquisitive study. When one black student did express misgivings and suggested that non-standard forms had been presented as if they were characteristic of all blacks, other black students criticized her for trying "to sweep the problem under the rug." My position, therefore, was greatly eased. Also, as is typical of extension courses, the students were older and more mature than the typical student on the main campus in Ann Arbor, and they were more pragmatic and less ideological in their outlook. Students in Ann Arbor may be filled with the abstract ideology that black is beautiful. They sometimes assert that black culture is superior to the wretched and imperialistic white culture. They may even lace their language with black slang. At the same time they may find it acutely embarrassing to face the possibility that blacks more often use stigmatized forms than do most whites. Hidden prejudices break through with which many students can hardly cope. Teachers in Flint know that their black students talk differently than their white students. They may have always attributed the differences to ignorance, laziness, intellectual inferiority, or even thick lips, but they are not so embarrassed by the fact of difference.

Finally, the class was relatively homogeneous. Most were teachers; few had studied any linguistics. The course was crosslisted as either Anthropology or Linguistics but it was not listed under Education and I warned them at the start that it was not a methods course. I told them they would get no magic answers to their practical problems, but only a general view of the nature of language and language variation. Thus, I avoided the worst demands for practical lesson plans and at the same time, the students were never threatened by mysterious questions from linguistically sophisticated classmates. I spent the twelve sessions available to me as follows. 
1) Language Variation. I began with a very general discussion of variability within English. I concentrated upon dialectal variables that involved no stigmatization (primarily geographical variables), and I capitalized upon variation among the dialects of members of the class. I tried to get across the idea of phonological contrast by demonstrating the differences among the students. I also spent a little time on lexical and syntactical variation, and gave them the assignment (to be submitted one week later) of finding a speaker with a dialect quite different from their own, and noting a few ways in which his pronunciation, grammar, and vocabulary differed.

2) Examples of social variation in languages used in other countries. Feeling that the topic of black and non-standard Englist might be made less emotional if it could be seen in the context of other more distant examples, I sketched some aspects of the sociolinguistic situation in Java, and in India, and I described diglossia. I concluded with an invitation to the class to suggest ways in which they felt that the situation in our country was similar to or different from the various examples I had given.

3) Linguistic and Sociological variables in the United States. I tried to clarify, more systematically than before, some significant sociological and linguistic variables. I tried to distinguish variables of geography from variables of social class and I tried to distinguish both of these from variation in style-particularly more and less formal styles. Cross cutting these sociological variables are the linguistic variables of vocabulary, grammar, and pronunciation. I spent the most time distinguishing several sorts of variation in pronunciation: 1) variation in individual words (e.g. syrup, economic, creek); 2) variation in sounds (or what we once fondly called "phonemes") that involves no loss of contrast, and 3) variation in contrast. These are subtle distinctions that required considerable exposition, but I felt they were necessary if non-standard phonology was to be described with any degree of cogency. In order to encourage the class to take these distinctions seriously and to help me to assess their understanding, I gave them a chart with fifteen cells. The three rows were labeled "geography," "class," and "style," and the five columns were labeled "vocabulary," "grammar," "word variation in pronunciation," "sound variation," and "contrast variation." In each cell, I gave one example (e.g. sneaker/tennis shoe in the geographical-lexical" cell; I don't have any/I have none, in the "stylistic-grammatical" cell), and I asked them to think up at least one additional example for each cell.

4) Language Deprivation Theories. I had expected to show the 
Bereiter-Engelmann film on "Language," and in preparation I had asked the class to read Chapter 2 of Bereiter and Engelmann (1966) called "Cultural Deprivation as Language Deprivation." The film failed to arrive, but we spent about half the session discussing the chapter. During the remainder of the session, I played a tape prepared by Roger Shuy of 21 Detroit speakers of various classes and both races, and $I$ asked them to guess the social affiliation of the various speakers. The students seemed to have been well enough prepared not to be threatened by this exercise, and indeed they went about the guessing game with considerable enthusiasm and skill. I pointed out at the end that the tape demonstrates clearly that whether we like it or not, we do judge people by the way they talk, and we are able to make our judgments with considerable, although not complete, accuracy. While demonstrating the differences, the tape also shows that, particularly at the upper social levels, it is not always possible to tell black speakers from whites, and this demonstrates that biological differences are not an important variable in determining how people talk.

5) Class Differences in Pronunciation: I described and explained some of the more important phonological variables that divide American social groups. I pointed out that the same kinds of variables found among white and standard speakers (e.g. loss of preconsonantal $r$, weakening of $l$ in certain positions, etc.) may also distinguish black speakers; but that blacks, at least in Michigan, are likely to carry the process of final consonant loss and cluster simplification further than most whites. I concluded by playing a tape I had made in Detroit of a 16-year old black youth, and we listened for the features I had been describing.

For the following week, I asked them to prepare a Policy Statement of the sort their school superintendent or their board of education might issue. They were to state succinctly the policy they would like to see their school systems take toward non-standard English.

6) Pronciation--II. The Bereiter-Engelmann film had now arrived. We watched it and discussed it. I solicited reactions from the class but did not, in the end, pretend to neutrality. I pointed out the ways in which I felt Bereiter and Engelmann show abysmal lack of understanding of the nature of language and of language variation. During the latter part of the session, I concluded my discussion of phonological differences and began to consider the implications of these differences for grammar. I pointed out that the loss of final consonants might threaten the loss of some suffixes.

7) Class Differences in Grammar. I concluded my discussion of suffixation and proceeded to an exposition of negative concord in 
various forms of non-standard English. Though this involved a number of technicalities, I hoped it would lead the class to appreciate the close relation among even the most divergent English dialects. As an assignment to be handed in one week later, I asked them to "translate" several standard English sentences (which I supplied) into some variety of non-standard English. This, I pointed out, was the reverse of what we often ask school children to do, and my students seemed to find it a rather intriguing assignment. I hoped it would stimulate them to consider the grammatical differences with some care.

8) Grammar-II. I had collected and read their Policy Statements and I now handed them back and we discussed the alternatives briefly. I then dictated a half dozen sentences that involved non-standard forms of question-embedding (e.g. I asked John if he would give me a book). We discussed the implication of their natural and unconscious "translation" for their own ability as teachers to "correct" their children, and we discussed the comparable situation of non-standard speakers who may understand standard English easily without having any clear awareness of how their own speech differs from standard.

I then continued my discussion of grammatical differences, considering in particular, modals and various types of questions.

9) Qualitative and Vocabulary differences. I began by challenging them to suggest criteria by which we might judge one dialect to be "better" than another. We considered, and I did my best to dispose of, differences in logic, clarity, sloppiness, and redundancy. I argued that only by sociological prejudice, and not by any sound linguistic principle, could one dialect be judged "better." I then discussed differences in vocabulary that divide various social groups from one another. I mentioned differences among professions and generations, but spoke particularly of slang. I also considered the reasons why vocabulary differences are so much less strongly stigmatized in this country than phonological or especially syntactical differences, and I considered the curious fact that vocabulary is regularly borrowed by whites from blacks in this country, while phonology and grammar seem more likely to be borrowed in the other direction. We discussed the implications of our different attitude toward vocabulary for our social system and for education.

10) Discussion of reading, and the origins of black English. We had discussed the assigned reading from time to time but I set the first half of this session aside specifically for this purpose. Besides the Bereiter and Engelmann (1966) chapter already mentioned, the students had been asked to read Labov's (1969) "The Logic of Nonstandard English," Sledd's (1969) "Bidialectalism: The Linguistics 
of White Supremacy," articles by Stewart and by Fasold and Wolfram in Baratz and Shuy's (1969) Teaching Black Children to Read, and a long section from the first part of Volume II of Labov et al. (1968) A Study of the Non-standard English of Negro and Puerto Rican Speakers in New York City. Their comments and questions suggested that the ideas in these readings were often very new but they seemed to have been received with interest and understanding.

I then discussed pidginization and creolization, and gave them an example from Melanesian Pidgin English. I discussed the dialectal and creole hypothesis for the origin of black English and tried to give a balanced view both of the facts these theories seem to explain, and of those which they do not explain. I. suggested that whatever its origin, black English is now so much like "white" English and that it grades so impercepttoly into white and standardEnglish, that it may be rather romantic to imagine black English to be a deeply different language requiring a sharply distinct pedagogical approach, but I also pointed out that there are differing opinions on this matter.

11) Implications for education. We continued our earlier discussion of alternative policies and discussed, in more concrete ways, the practical steps by which these policies might be implemented. I suggested that hardly anyone (certainly not most black parents) wanted to stop teaching standard English. There are, however, questions about when it should be taught (grade school, junior high, senior high, etc.) and about what aspects should be taught (reading comprehension, speaking with standard grammar, speaking with standard pronunciation, etc.). We discussed techniques by which these various goals might be accomplished.

12) Final Examination

Conclusions

Only a little wandering around ghetto schools is needed to persuade a linguist that teachers need help. Linguistic mistakes are easy to observe, and since they are made through ignorance, not through irresponsibility or stupidity, the desire to bring enlightenment to the benighted can become overwhelming. But linguists who hope to build bridges to the public schools must learn to be content with modest goals. The process will be long and slow. Teachers have undergone repeated blandishments from many sides to do this or to do that. They have heard endless promises that this technique or that technique will solve their problems. Any sensible teacher learns to be skeptical of such promises, and she will be quite properly skeptical of the linguist who proclaims his own new 
set of solutions. We can try for a long and slow process of reeducation, but we must not be disappointed when miracles fail to occur. We must be content with small rewards. A few of the experiences that made teaching in Flint worthwhile to me may suggest the sorts of rewards for which I think others might legitimately hope:

- The refined and gracious black woman who, when responding to my inquiry about who did and who did not make a contrast between pin and pen, said, with a twinkle in her eye, "I only make a difference when I'm trying to be cute," and thereby reduced the matter to the precise point of triviality where it belongs.

--The middle-aged white teacher who, the week after I had discussed variation in such verb forms as laughing and laughin', said to the class, "When you talked about-ing and - in' last week, I thought I always said -ing, but I caught myself saying -in', and I'm sure if I said it once I must say it other times too."

--The teacher who took one of her assignments to school and discussed it in the teachers' lounge. She told me that a large group of teachers, both black and white, had a fascinating discussion comparing aspects of their speech that they had never thought about before.

-- The woman who told me how interested her own fifth grade students were in her reports of what she had been learning in class. She told me of many lively class discussions in which her students compared their own linguistic usages.

- The white teacher who, when comforting a first grader who had been terrified by a barking dog, caught herself imitating the distinctively non-standard grammar of the child. Instead of being appalled at her own behavior, she was able to tell me about it with considerable pride.

One who can be content with such modest rewards, can find teaching teachers to be a satisfying, if occasionally still frustrating, experience.

\section{REFERENCES}

Baratz, Joan C. and Roger Shuy (Eds.). 1969. Teaching Black Children to Read. Washington, D.C.: Center for Applied Linguistics.

Bereiter, Carl and Siegfried Engelmann. 1966. Teaching Disadvantaged Children in the Preschool. Englewood Cliffs, New Jersey: PrenticeHall.

Labov, William. 1969. The logic of non-standard English. In James Alatis (Ed.), Report of the Twentieth Annual Round Table Meeting on Linguistics and Language Studies (1-43). Washington, D.C.: Georgetown University Press. 
Labov, William, Paul Cohen, Clarence Robins, and John Lewis. 1968. A Study of the Non-Standard English of Negro and Puerto Rican Speakers in New York City. Final Report, Cooperative Research Project No. 3288. Office of Education, Washington, D.C. Vols. I and II.

Sledd, James. 1969. Bidialectalism: the linguistics of white supremacy. English Journal 58.1307-1315. 